Journal of Animal and Veterinary Advances 11 (2): 234-240, 2012

ISSN: $1680-5593$

(C) Medwell Journals, 2012

\title{
Antimicrobial Activities of Selected Mangrove Plants on Fish Pathogenic Bacteria
}

\author{
${ }^{1}$ A.A. Laith, ${ }^{1}$ M. Najiah, ${ }^{1}$ S.M. Zain, ${ }^{2}$ S.H.M. Effendy A.W., \\ ${ }^{3}$ T. Sifzizul T.M., ${ }^{1}$ M. Nadirah and ${ }^{2}$ M. Habsah \\ ${ }^{1}$ Department of Fisheries and Aquaculture, Faculty of Agrotechnology and Food Science, \\ ${ }^{2}$ Institute of Marine Biotechnology, ${ }^{3}$ Department of Biological Sciences, \\ Universiti Malaysia Terengganu, 21030 Kuala Terengganu, Terengganu, Malaysia
}

\begin{abstract}
The objective of this study was to conduct in vitro study of antimicrobial properties of mangrove plants Sonneratia caseolaris and Rhizophora apiculata against fish pathogenic bacteria. Leaves of mangrove plant were collected from area nearby University Malaysia Terengganu. Methanol extracts of mangrove plants were obtained by using Soxhlet extractor. The bacterial cultures used were Klebsiella pneumoniae, Shigella dysenteriae, Enterobacter cloacae, Enterobacter sakazakii, Enterobacter brevis, Chryseobacterium indologenes, Stenotrophomonas maltophilia and Aeromonas hydrophila isolated from fish. The antimicrobial susceptibility test showed that the bacteria were $87.5 \%$ resistant towards colistin sulphate and $62.5 \%$ sensitive to fosfomycin. The Minimum Inhibitory Concentration (MIC) of Sonneratia caseolaris and Rhizophora apiculata ranges from 1.56-6.25 and 12.5-25 mg mL $\mathrm{m}^{-1}$, respectively. The lowest Minimum Bactericidal Concentration (MBC) value was $12.5 \mathrm{mg} \mathrm{mL}^{-1}$ of Sonneratia caseolaris and $25 \mathrm{mg} \mathrm{mL} \mathrm{m}^{-1}$ of Rhizophora apiculata. The highest activity with $\mathrm{LC}_{50}$ of Sonneratia caseolaris was $6.16 \mathrm{mg} \mathrm{mL} \mathrm{m}^{-1}$ and Rhizophora apiculata was $0.76 \mathrm{mg} \mathrm{mL}^{-1}$, respectively. Methanol extracts of Sonneratia caseolaris was effective on all gram negative bacteria (Klebsiella pneumoniae, Shigella dysenteriae, Enterobacter cloacae, Enterobacter sakazakii, Enterobacter brevis, Chryseobacterium indologenes, Stenotrophomonas maltophilia and Aeromonas hydrophila) when compared to Rhizophora apiculata.
\end{abstract}

Key words: Antimicrobial activities, mangrove plant, $\mathrm{M} C, \mathrm{MBC}, \mathrm{LC}_{50}$, Malaysia

\section{INTRODUCTION}

Mangrove plants, Sonneratia caseolaris and Rhizophora apiculata are normally used in traditional medicine for the treatment of several illnesses caused by microbial and non-microbial origins (Xie et al., 2005). Mangrove plant has traditionally been used to treat sores and stings from marine creatures and ulcers as a purgative and an emetic and the smoke from the bark to treat leprosy (Ghani, 2003). Mangrove contains biologically active antibacterial, antifungal and antiviral compounds (Vadlapudi and Naidu, 2009).

Mangroves have been a source of several bioactive compounds. Mangrove plants have been used in folklore medicines and extracts from mangrove species have proven activity against human, animal and plant pathogens. Secondary metabolites like alkaloids, phenolics, steroids and terpenoids have been characterized from mangroves and have toxicological, pharmacological and ecological importance (Kokpal et al., 1990). They provide a prosperous source of alkaloids, steroids, triterpenoids and flavonoids (Abeysinghe, 2010). Antibacterial activity of mangroves against fish pathogens had already been studied by many researchers. Lim et al. (2006) showed in their study of antimicrobial activities of tannins extracted from mangrove plant Rhizophora apiculata barks was significant antibacterial activity. Mishra and Sree (2007) reported the chloroform leaf extract of mangrove plant Finlaysonia obovata showed strong antibacterial activity against fish pathogens (Manilal et al., 2009).

Three mangrove species (Avicennia marina, Bruguiera cylindrical and Acanthus ilicifolius) collected from the coast was extracted in methanol and tested for different range of biological activities including antimicrobial activity against five species of type cultures (microbial type culture collection) of fish/shrimp Vibrio pathogens, brine shrimp cytotoxic,

Corresponding Author: A.A. Laith, Department of Fisheries and Aquaculture, Faculty of Agrotechnology and Food Science, Universiti Malaysia Terengganu, 21030 Kuala Terengganu, Terengganu, Malaysia 
antifouling and ichthyotoxic activities. Antibacterial compounds from natural resources would be the alternative to overcome the resistance problem (Kumar et al., 2009). Antimicrobial activities of 5 Indian mangrove plants (Rhizophora apiculata, Rhizophora mucronata, Bruguiera cylindrica, Ceriops decandra and Avicennia marina) against UTIs bacterial pathogens studied by Ravikumar et al. (2010). The antimicrobial activity of the methanol extracts from leaves of the mangrove plant, Sonneratia caseolaris and Rhizophora apiculata against fish pathogenic bacteria were studied.

\section{MATERIALS AND METHODS}

Plant material: Two plants were used in this study, Sonneratia caseolaris and Rhizophora Apiculata. The leaves were collected from a rural area of Mengabang Telipot in Terengganu, Malaysia. The plants were identified at the plant taxonomy laboratory in Universiti Malaysia Terengganu.

The weight of the leaves after extraction was weighed using a weighing balance to determine the percentage yield of the crude extract using the equaction:

$$
\text { Percentage yield }=\frac{\mathrm{X}_{1}-\mathrm{X}_{2}}{\mathrm{X}_{1}} \times 100
$$

Where:

$\mathrm{X}_{1}=$ Weight of the dry powdered leaves before extraction (15.0 g)

$\mathrm{X}_{2}=$ Weight of the dry leaves after extraction

The weight or mass of crude methanolic extract can be calculated using the equaction:

$$
\text { Percentage yield }=\frac{\mathrm{X}_{1}}{100}
$$

Preparation of extracts: The leaves of plants were washed with both tap and distilled water to remove any epiphytes present and other wastes and they were then air dried under the shade for 3 weeks. The dried plant material was ground to fine powder ( $15 \mathrm{~g}$ dry weight) and was then extracted with $100 \mathrm{~mL}$ of methanol for $48 \mathrm{~h}$ using a soxhlet extractor according to the methods of (Bele et al., 2009) and then the extract were filtered through a Buchner funnel and using Whatman no. 1 filter paper. This was repeated three times for the complete extraction of methanol-soluble compounds and all the three methanol extracts were pooled. The solvent was evaporated from crude extract by a rotator evaporator. The dried extracts were stored at $4^{\circ} \mathrm{C}$ until further use. Percentage yield was calculated from the dry extract powder. About $3,250 \mathrm{mg} \mathrm{mL} \mathrm{mL}^{-1}$ of the extracts were dissolved in methanol for the antibacterial assays and in Dimethyl Sulfoxide (DMSO) for cytotoxicity assays. The samples in DMSO for cytotoxicity screening were further diluted to $5 \mathrm{mg} \mathrm{mL}^{-1}$ with growth medium (DMEM or RPMI 1640) to reduce the percentage of DMSO.

Test organisms: Eight bacterial pathogens namely Klebsiella pneumoniae, Shigella dysenteriae, Enterobacter cloacae, Enterobacter sakazakii, Enterobacter brevis, Chryseobacterium indologenes, Stenotrophomonas maltophilia and Aeromonas hydrophila were identified by using a commercial Identification system kit (BBL TM Crystal E/NF, USA). The pathogenic bacteria were cultured individually on Tryptic Soy Broth (TSB) (Merk, Germany) at $37^{\circ} \mathrm{C}$ for $18 \mathrm{~h}$, before inoculation for assay. Broth culture $(100 \mu \mathrm{L})$ which contained 108 number of bacteria per $\mathrm{mL}$ (the inoculums size of each test strain were standardized at $108 \mathrm{cfu} \mathrm{mL}^{-1}$ using McFarland Nephelometer standard). Sterile Tryptic Soy Agar (TSA) (Merk, Germany) plates were seeded with test bacterial strains and allowed to stand at $37^{\circ} \mathrm{C}$ for $24 \mathrm{~h}$.

In vitro anitbiogram of isolates: Antibiogram tests for the isolate were performed using the disc diffusion technique on Tryptic Soy Agar. NCCLS (2001) guidelines were used for evaluation of the results. All the bacteria isolated were tested in vitro for their sensitivity to 10 different antibiotics. These included Nitrofurantion (50 ug), Colistin sulphate (25 ug), Fosfomycin $50(\mathrm{ug})$, Lincomycin (15 ug), Tetracycline (30 ug), Spiramycin (100 ug), Oxolinic acid (2 ug), Florfenciol (30 ug), Amoxycilin (25 ug) and Erythromycin (15 ug).

\section{Antibacterial assay}

Disk diffusion assay: Disk diffusion assay was carried out on Tryptic Soy Agar (TSA) (Merk, Germany) following the method described by Barker and Kehoe (1995). Briefly from the plant extracts, $350 \mathrm{mg}$ of crude extracts were dissolved in $1 \mathrm{~m}, 4 \%$ Dimethyl Sulphoxide (DMSO) and $0.2 \mathrm{~mL}$ of the prepared extracts were loaded on to the filter paper discs (sterilized Whatman no. 1 filter paper discs $6 \mathrm{~mm}$ in diameter) to get $20 \mathrm{ug} \mathrm{disc}{ }^{-1}$ concentration and allowed to dry at room temperature in laminar air flow chamber. Positive control (Neomycin $10 \mu \mathrm{g} \mathrm{mL}^{-1}$ ) and negative control (methanol) disc were allowed to air dry and were then placed equidistantly onto the surface of the pathogen seeded Tryptic Soy Agar plates. The plates were stored in an inverted position and incubated at $37^{\circ} \mathrm{C}$ for $18 \mathrm{~h}$. The growth inhibition was assessed as the diameter $(\mathrm{mm})$ of the zone of inhibited microbial growth. The experiment was carried out three times. 
Agar-well diffusion method: The bacterial isolates were first grown in nutrient broth for $24-48 \mathrm{~h}$ before use. The isolates were then subcultured on to Tryptic Soy Agar plates (Oxoid, Ltd.). The wells were then bored into the agar medium using a sterile $6 \mathrm{~mm}$ cork borer. The wells were then filled up with solution of the extract and intense care was taken as to not allow the solution to spill on the surface of the medium. The plates were allowed to stand on the laboratory bench between 1-2 $\mathrm{h}$ to allow proper inflow of the solution into the medium. Subsequently, the plates were placed in an incubator at $37^{\circ} \mathrm{C}$ for $24 \mathrm{~h}$ (Adegboye et al., 2008).

The plates were later observed for their zones of inhibition. The effects of the extract on bacterial isolates were compared with those of standard antibiotics tetracycline at a concentration of $10 \mathrm{ug} \mathrm{mL}^{-1}$. The experiment was carried out in triplicate. Experimental data represent mean of each sample:

$$
\text { Antimicrobialindex }=\frac{\text { Inhibition zone of sample }}{\text { Inhibition zone of the standard }} \times 100
$$

Determination of Minimum Inhibitory Concentration (MIC): Minimum inhibitory concentration was determined by broth micro-dilution assay technique in 96 wells micro-titer plates as described by Eloff (1998) with slight modification. Overnight broth cultures of the each test organism $(90 \mathrm{uL})$ were seeded into the wells and crude metabolite $(10 \mathrm{uL})$ were added in each well at decreasing concentration starting from $1000-75 \mathrm{ug} \mathrm{mL} \mathrm{mL}^{-1}$. The plates were incubated for $24 \mathrm{~h}$ at $35 \pm 1^{\circ} \mathrm{C}$ and TTC solution $1 \%$, sterile (Triphenyl Tetrazolium Chloride) were used as microbial growth indicator. $\mathrm{MC}$ was determined as the least concentration of the crude metabolite that inhibited the growth of the test organisms.

Minimum Bactericidal Concentrations (MBC): The MBC of the extract was determined using Ilavenil et al. (2010) method with little modifications. Samples were taken from the plates with that displayed negative visible growth in the $\mathrm{MIC}$ assay and were subcultured on to a freshly prepared nutrient agar medium and later incubated at $37^{\circ} \mathrm{C}$ for $48 \mathrm{~h}$. The MBC was determined as the lowest concentration of the extract that did not allow any bacterial growth on the surface of the agar plates. The experiments were carried out in three replicates and the mean readings were recorded.

The results were determined according to the ratio of $\mathrm{MBC} / \mathrm{MIC}$. If the ratio of $\mathrm{MBC} / \mathrm{MLC}$ was $\leq 2$ the active fractions were considered to be bactericidal; otherwise, they were considered bacteriostatic. And if the ratio was $\geq 16$ the fractions were considered to be ineffective (Manilal et al., 2010).

\section{Brine shrimp larvae assay}

Brine shrimp egg hatching: Brine shrimp eggs (Artemia Salina, SandersTM Great Salt Lake, Brine Shrimp Company L.C., USA) were hatched in artificial seawater at $20^{\circ} \mathrm{C}$ and constant illumination. The brine shrimp eggs were incubated in a polypropylene jar with a water height of $1.2 \mathrm{~cm}$. These hatching conditions corresponded to those in the natural environment. After $48 \mathrm{~h}$ incubation at room temperature $\left(25-29^{\circ} \mathrm{C}\right)$, nauplii (larvae) were collected using a pipette taken from the lighter side whereas their shells were left in another side the shrimp larvae were used for experimental bioassay. During that time, the larvae were still surviving on their own yolk sac and have received no further food during the experimental duration.

Bioassay: Brine shrimp lethality assay, following the modified method of Pisutthanana et al. (2004) were carried out to study the general toxicity of the extract of Sonneratia caseolaris and Rhizophora apiculata. About $10 \mathrm{mg}$ of the extracts were added to $2 \mathrm{mg} \mathrm{mL}^{-1}$ of artificial sea water mixture. The mixture contained water insoluble compounds which were dissolved in DMSO $50 \mu \mathrm{L}$ prior to the addition into the sea water. Serial dilutions were completed using 96 well micro plates and were performed in triplicate in $120 \mu \mathrm{L}$ sea water. Control wells with DMSO were included in each experiment. A $100 \mu \mathrm{L}$ suspension of nauplii (containing 10-15 organisms) were added to each well. The plates were then covered and incubated at room temperature $\left(25-29^{\circ} \mathrm{C}\right)$ for $24 \mathrm{~h}$. Plates were then examined under binocular steromicroscope and the numbers of dead, non-motile nauplii in each well were counted. Finally, all shrimps were scarified by adding $100 \mu \mathrm{L}$ of methanol to each well. After $15 \mathrm{~min}$, the total numbers of shrimps in each well were counted. Analysis of the data was performed using PROBIT analysis on a finney computer program. Analysis was executed to determine the lethal concentration required to kill half the population of the test organisms during the period of $24 \mathrm{~h}\left(\mathrm{LC}_{50}\right)$. The toxicity is expressed by the $\mathrm{LC}_{50}$.

$$
\text { Mortality }(\%)=\frac{\text { No. of dead nauplii }}{\text { Initial no. of live nauplii }} \times 100
$$

Statistical analysis: The experiments were conducted three times and the mean readings were recorded.

\section{RESULTS AND DISCUSSION}

The Antimicrobial Susceptibility Test (AST) is an important technique in many disciplines of science. It is used in pathology to determine the resistance of microbial strains to antimicrobials and is used to determine the 
J. Anim. Vet. Adv., 11 (2): 234-240, 2012

Table1: Antibiogram of fish pathogenic bacteria

\begin{tabular}{|c|c|c|c|c|c|c|c|c|c|c|c|}
\hline \multirow{2}{*}{$\begin{array}{l}\text { Antibiotics } \\
\text { disc }\end{array}$} & \multirow{2}{*}{$\begin{array}{l}\text { Potency } \\
\text { (mcg) }\end{array}$} & \multicolumn{8}{|c|}{ Isolates } & \multicolumn{2}{|c|}{ Percentage } \\
\hline & & 1 & 2 & 3 & 4 & 5 & 6 & 7 & 8 & $\mathrm{R}$ & $\mathrm{S}$ \\
\hline Nitrofurantion & 50 & $\mathrm{~s}$ & $\mathrm{R}$ & $\mathrm{R}$ & $\mathrm{R}$ & I & I & $\mathrm{I}$ & I & 37.50 & 12.5 \\
\hline Colistin sulphate & 25 & $\mathrm{R}$ & $\mathrm{R}$ & $\mathrm{R}$ & $\mathrm{R}$ & $\mathrm{R}$ & $\mathrm{R}$ & $\mathrm{s}$ & $\mathrm{R}$ & 87.50 & 12.5 \\
\hline Fosfomy cin & 50 & $\mathrm{R}$ & $\mathrm{s}$ & $\mathrm{S}$ & $\mathrm{s}$ & $\mathrm{R}$ & $\mathrm{s}$ & I & $\mathrm{s}$ & 25.00 & 62.5 \\
\hline Linconty cin & 15 & $\mathrm{~s}$ & $\mathrm{R}$ & $\mathrm{R}$ & $\mathrm{S}$ & $\mathrm{R}$ & $\mathrm{S}$ & $\mathrm{R}$ & $\mathrm{s}$ & 50.00 & 50.0 \\
\hline Tetracycline & 30 & $\mathrm{~s}$ & $\mathrm{R}$ & $\mathrm{R}$ & $\mathrm{s}$ & $\mathrm{R}$ & $\mathrm{R}$ & $\mathrm{s}$ & $\mathrm{R}$ & 62.50 & 37.5 \\
\hline Spiramy cin & 100 & $\mathrm{R}$ & $\mathrm{R}$ & $\mathrm{R}$ & I & I & I & $\mathrm{s}$ & I & 37.50 & 12.5 \\
\hline Oxolinic acid & 2 & $\mathrm{~s}$ & $\mathrm{R}$ & $\mathrm{R}$ & $\mathrm{s}$ & $\mathrm{R}$ & $\mathrm{s}$ & $\mathrm{R}$ & I & 50.00 & 37.5 \\
\hline Florfenciol & 30 & $\mathrm{~S}$ & $\mathrm{R}$ & $\mathrm{R}$ & $\mathrm{s}$ & $\mathrm{R}$ & $\mathrm{s}$ & $\mathrm{s}$ & $\mathrm{S}$ & 37.50 & 62.5 \\
\hline Amoxycilin & 25 & I & $\mathrm{R}$ & $\mathrm{R}$ & $\mathrm{R}$ & $\mathrm{R}$ & I & $\mathrm{R}$ & I & 62.50 & 0.0 \\
\hline Erythromy cin & 15 & I & $\mathrm{R}$ & $\mathrm{R}$ & $\mathrm{s}$ & $\mathrm{R}$ & I & $\mathrm{R}$ & I & 50.00 & 12.5 \\
\hline MAR & - & - & 0.03 & 0.11 & 0.11 & 0.03 & 0.1 & 0.02 & 0.05 & 0.02 & - \\
\hline
\end{tabular}

$\mathrm{R}$ = Resistant; I = Intermediate; $\mathrm{S}=$ Sensitive; 1: Shigella dysenteriae; 2: Enterobacter cloacae; 3: Klebsiella pneumoniae; 4: Enterobacter sakazakii;

5: Enterobacter brevis; 6: Chryseobacterium indologenes; 7: Stenotrophomas maltophilia, 8: Aeromonas hydrophila; MAR: Multiple Antibiotic Resistant

Table 2: Antibiotics references according to National Committee for Clinical Laboratory Standards (CLSI) with Escherichia coli ATCC 25922 as quality control

\begin{tabular}{lrrr}
\hline & Zone of inhibition (mm) & \\
\cline { 2 - 4 } Antibiotics disc & \multicolumn{1}{c}{ R } & \multicolumn{1}{c}{ I } & S \\
\hline Nitrofurantion & 12 & $13-15$ & 16 \\
Colistin sulphate & 8 & $9-10$ & 11 \\
Fosfony cin & 13 & $14-16$ & 17 \\
Linconycin & 14 & $15-20$ & 21 \\
Tetracycline & 14 & $15-18$ & 19 \\
Spiramycin & 12 & $13-15$ & 16 \\
Oxolinic acid & 14 & $15-17$ & 18 \\
Florfenciol & 14 & $15-17$ & 18 \\
Amoxycilin & 13 & $14-17$ & 18 \\
Erythromycin & 13 & $14-22$ & 23
\end{tabular}

efficacy of novel antimicrobials against micro-organisms, essentially those of medical importance. The AST is the first step towards new anti-infective drug development. There are various AST methods that are used by researchers and these could lead to variations in results obtained. The bacterial isolates were subjected to 10 antibiotics for testing their susceptibility (Table 1). The results demonstrate that the isolates were sensitive to fosfomycin $(62.5 \%)$ and are resistant towards colistin sulphate $(87.5 \%)$. There was no evidence of Multiple Antibiotic Resistant (MAR) in this study. The range of mean zone of inhibition for concentration 100,300 and $500 \mathrm{mg} \mathrm{mL} \mathrm{mL}^{-1}$ by using well technique was 15,18 and $19.25 \mathrm{~mm}$ for methanol extracts of Sonneratia caseolaris and $10.5,13.12,14.12 \mathrm{~mm}$, respectively for methanol extracts of Rhizophora apiculata while the mean zone of inhibition for positive control tetracycline was $14.62 \mathrm{~mm}$ (Table 2).

The mean zone of inhibition for methanol extracts of Sonneratia caseolaris and Rhizophora apiculata concentration $500 \mathrm{mg} \mathrm{mL}^{-1}$ by using disk diffusion method was 13.8 and $9 \mathrm{~mm}$, respectively while the mean zone of inhibition for positive control neomycin was $11.5 \mathrm{~mm}$ (Table 3 ). The antimicrobial activity of the extracts and their potency were quantitatively assessed by determining their $\mathrm{MIC}$ and $\mathrm{MBC}$, respectively. The $\mathrm{MIC}$ values were between 1.56 and $6.25 \mathrm{mg} \mathrm{mL}^{-1}$ for the methanol extracts of Sonneratia caseolaris while it was 12.5 and $25 \mathrm{mg} \mathrm{mL}^{-1}$ for methanol extracts of Rhizophora apiculata (Table 4). The lowest MBC value was $12.5 \mathrm{mg} \mathrm{mL}$ for Sonneratia caseolaris and $25 \mathrm{mg} \mathrm{mL}^{-1}$ for Rhizophora apiculata.

The toxicity of extracts of Sonneratia caseolaris and Rhizophora apiculata were tested by brine shrimp bioassay. The average LC 50 for Sonneratia caseolaris was $6.16 \mathrm{mg} \mathrm{mL}-1$ and Rhizophora apiculata was $0.76 \mathrm{mg} \mathrm{mL}^{-1}$ (Table 5). The use of plant extracts with medicinal potential represents a valid substitute for the treatment of different ailments and diseases. The search for antimicrobial agents from plants has been a growing interest in the last few decades and plant materials continue to play a chief role in primary health care as therapeutic solutions in many developing countries (Alim et al., 2009). Sonneratia caseolaris and Rhizophora apiculata are known for their antimicrobial activities (Kumar et al., 2009).

In the present study, we report the effect of Sonneratia caseolaris and Rhizophora apiculata extracts on pathogenic fish bacteria in vitro. The observation indicates that the methanol extract of the leaves of Sonneratia caseolaris were effective against all the bacterial strains used in this study which is in agreement with Devi et al. (1997). Desai and Chavan (2010) who reported that the methanolic extracts of leaf, stem, young seed, mature seed and seed coat showed a high antibacterial activity against Pseudomonas aerunginosa as compared to ethanolic extracts products.

The disc diffusion (Bauer et al., 1966) is a widely accepted in vitro investigation for preliminary screening of test agents which may possess antimicrobial activity. It is essentially a quantitative or qualitative test indicating the resistance of the microorganisms to the test materials. However, no distinction between bacteriostatic and 
Table 3: In vitro screening of crude methanolic extract S. casiolares and R. apiculata on growth of pathogenic bacteria Zone of inhibition (Diameter mm)

\begin{tabular}{|c|c|c|c|c|c|c|c|}
\hline \multirow[b]{2}{*}{ Strain } & \multicolumn{3}{|c|}{ Sonneratia casiolares (mg) } & \multicolumn{3}{|c|}{ Rizophora apiculata (mg) } & \multirow{2}{*}{$\begin{array}{l}\text { Control } \\
\text { Tetracyclin } 10 \mathrm{ug} \mathrm{mL}^{-1}\end{array}$} \\
\hline & 100 & 300 & 500 & 100 & 300 & 500 & \\
\hline Shigella dysenteriae & 17 & 19 & 21 & 14 & 12 & 14 & 22 \\
\hline Enterobacter cloacae & 12 & 13 & 16 & 10 & 11 & 11 & 10 \\
\hline Klebsiella pneumonia & 15 & 19 & 18 & 15 & 17 & 18 & 09 \\
\hline Enterobacter sakazaki & 15 & 18 & 21 & 12 & 14 & 15 & 23 \\
\hline Enterobacter brevis & 14 & 20 & 21 & 10 & 12 & 13 & 11 \\
\hline Chryseobacterium indologenes & 16 & 19 & 19 & 14 & 14 & 14 & 20 \\
\hline Stenotrophomas maltphila & 13 & 17 & 19 & 09 & 13 & 15 & 06 \\
\hline Aeromonas hydrophilia & 16 & 19 & 19 & 11 & 12 & 13 & 16 \\
\hline
\end{tabular}

Table 4: Antimicrobial activity of methanolic extract of Sonneratia casiolares and Rizophora apiculata (Disc diffusion method)

\begin{tabular}{|c|c|c|c|c|}
\hline Bacteria strain & $\begin{array}{l}\text { Sonneratia casiolares } \\
\quad\left(500 \mathrm{mg} \mathrm{mL}^{-1}\right)\end{array}$ & $\begin{array}{l}\text { Rizophora apiculata } \\
\left(500 \mathrm{mg} \mathrm{mL}^{-1}\right)\end{array}$ & $\begin{array}{c}\text { Neomycin } \\
\left(10 \mathrm{ug} \mathrm{mL}^{-1}\right)\end{array}$ & $\begin{array}{c}\text { Methanol } \\
\text { MBC }(10 \%)\end{array}$ \\
\hline Shigella dysenteriae & 17 & 11 & 15 & 0 \\
\hline Enterobacter cloacae & 17 & 10 & 09 & 0 \\
\hline Klebsiella pneumonia & 12 & 09 & 10 & 0 \\
\hline Enterobacter sakazaki & 11 & 10 & 17 & 0 \\
\hline Enterobacter brevis & 18 & 10 & 10 & 0 \\
\hline Chryseobacterium indologenes & 14 & 08 & 16 & 0 \\
\hline Stenotrophomas maltphila & 09 & 06 & 05 & 0 \\
\hline Aeromonas hydrophilia & 14 & 08 & 11 & 0 \\
\hline
\end{tabular}

Table 5: Antimicrobial activity of plant extracts corresponding to their Minimal Inhibitory Concentrations (MIC) and Minimal Bacteriocidal Concentrations (MBC) in $\mathrm{mg} \mathrm{mL}^{-1}$

\begin{tabular}{|c|c|c|c|c|}
\hline \multirow[b]{2}{*}{ Bacteria strain } & \multicolumn{2}{|c|}{ Sonneratia casiolares } & \multicolumn{2}{|c|}{ Rizophora apiculata } \\
\hline & MIC & $\mathrm{MBC}$ & $\mathrm{MIC}$ & $\mathrm{MBC}$ \\
\hline Shigella dysenteriae & 6.25 & 25.0 & 25.0 & 50 \\
\hline Enterobacter cloacae & 6.25 & 12.5 & 25.0 & 50 \\
\hline Klebsiella pneumonia & 6.25 & 25.0 & 25.0 & 50 \\
\hline Enterobacter sakazaki & 1.56 & 12.5 & 12.5 & 25 \\
\hline Enterobacter brevis & 1.56 & 12.5 & 25.0 & 25 \\
\hline $\begin{array}{l}\text { Chryseobacterium } \\
\text { indologenes }\end{array}$ & 6.25 & 12.5 & 12.5 & 25 \\
\hline Stenotrophomas maltphila & 6.25 & 12.5 & 25.0 & 25 \\
\hline Aeromonas hydrophilia & 6.25 & 25.0 & 12.5 & 50 \\
\hline
\end{tabular}

bacteriocidal activity can be made by this method. The diameters of the zones of inhibition shown by the methanol extract against the pathogenic bacteria are similar to those reported by Chandrasekaran et al. (2009). In his study, the methanol extracts of E. agallocha showed the highest anti-MRSA activity with a mean zone of inhibition of $22.5 \mathrm{~mm}$ and Kumar et al. (2009) reported the mangrove leaf extracts of $E$. agallocha showed maximum inhibitory activity of $18 \mathrm{~mm}$ against $S$. Aureus and $R$. mucronata exhibited higher activity of $20 \mathrm{~mm}$ against $S$. lactis. The difference between the antimicrobial activities of mangroves could be due to the quantity of antimicrobial substances present in each form (Chandrasekaran et al., 2009). These might refer to the presence of coumarins, flavonoids and saponins as chemical components of these plants (Bonjar et al., 2004) and indicate that the methanol extract of the leaves of Sonneratia caseolaris has almost the same activity as the standard antibiotic. The sensitivity of pathogenic bacteria to Sonneratia caseolaris and Rhizophora apiculata extracts could be attributed due the presence of common bioactive compounds that had inhibitory effects on the microorganism agree with (Manilal et al., 2009).

MIC results can indirectly predict the concentration of extract which should be used as minimum dosage. The $\mathrm{MIC}$ values were between 1.56 and $6.25 \mathrm{mg} \mathrm{mL}^{-1}$ for the methanol extracts of Sonneratia caseolaris while it was 12.5 and $25 \mathrm{mg} \mathrm{mL}^{-1}$ for methanol extracts of Rhizophora apiculata. The lowest MBC value was $12.5 \mathrm{mg} \mathrm{mL}^{-1}$ for Sonneratia caseolaris and $25 \mathrm{mg} \mathrm{mL}^{-1}$ for Rhizophora apiculata, the results were in agreement with Lim et al. (2006) and Patra (2009). A similar result was reported by Sharma et al. (2009) in their studies on the vibriocidal activities of 16 Indian medicinal plants where in $70 \%$ of the Vibrio pathogens tested were susceptible to the plant extract at a concentration ranging between 2.5 and $20 \mathrm{mg} \mathrm{mL}^{-1}$ and the study result of Chandrasekaran et al. (2009) who recorded the MIC value of the methanol extracts of $E$. agallocha which was $0.125 \mathrm{mg} \mathrm{mL}^{-1}$ and the $\mathrm{MBC}$ was $0.25 \mathrm{mg} \mathrm{mL}^{-1}$. Which agrees with the result of the microorganism test which had a low MIC values and showed low concentrations of MBC.

The results showed that the extract exhibited bacteriostatic ( $\mathrm{Lim}$ et al., 2006). In general gram-positive bacteria are considered to be more sensitive than gram-negative bacteria towards different antimicrobial compounds because of the difference in the structure of 
their cell walls (Scherrer and Gerhardt, 1971). The brine shrimp assay is a simple and useful tool for the isolation of potentially cytotoxic compounds from plant extracts (Meyer et al., 1982). The Brine Shrimp Lethality Assay (BSLA) has been used routinely in the primary screening of the crude extracts as well as isolated compounds to assess the toxicity towards brine shrimp which could also provide an indication of possible cytotoxic properties of the test materials.

The results agree with Subhan et al. (2008) who found that the extract of mangrove plant E. agallocha showed considerable brine shrimp toxicity $\left(\mathrm{LC}_{50}=20 \mathrm{mg}\right.$ $\mathrm{mL}^{-1}$ ) and the variation in the BSLA results may be due to the difference in the amount and kind of cytotoxic substances (e.g., tannins, flavonoids or triterpenoids) present in the extracts.

\section{CONCLUSION}

Based on the screening results, Sonneratia caseolaris has been shown possessing antibacterial potential to combat the fish pathogenic bacteria. Bioactive compound of the mangrove plants will be determined in the future studies.

\section{ACKNOWLEDGEMENT}

This project was supported by the Ministry of Agriculture (MOA), Malaysia, grant No: 05-01-12-SF1009.

\section{REFERENCES}

Abeysinghe, P., 2010. Antibacterial activity of some medicinal mangroves against antibiotic resistant pathogenic bacteria. Indian J. Pharm. Sci., 72: 167-172.

Adegboye, M.F., D.A. Akinpelu and A. Okoh, 2008. The bioactive and phytochemical properties of Garcinia kola (Heckel) seed extract on some pathogens. Afr. J. Biotechnol., 7: 3934-3938.

Alim, A., I. Goze, H.M. Goze, B. Tepe and J. Serkedjieva, 2009. In vitro antimicrobial and antiviral activities of the essential oil and various extracts of Salvia cedronella Boiss. J. Med. Plants Res., 3: 413-419.

Barker, G.A. and E. Kehoe, 1995. Assessment of disc diffusion methods for susceptibility testing of Aeromonas salmonicida. Aquaculture, 134: 1-8.

Bauer, A.W., W.M. Kirby, J.C. Sherris and M. Turck, 1966. Antibiotic susceptibility testing by a standard B single disc method. Am. J. Clin. Pathol., 45: 493-496.
Bele, A.A., V.M. Jadhav, S.R. Nikam and V.J. Kadam, 2009. Antibacterial potential of herbal formulation. Res. J. Microbiol., 4: 164-167.

Bonjar, G.H.S., S. Aghighi and A.K. Nik, 2004. Antimicrobialand antifungal survey in plants used in endogenous herbal-medicine of south east regions of Iran. J. Biol. Sci., 4: 405-412.

Chandrasekaran, M., K. Kannathasan, V. Venkatesalu and K. Prabhakar, 2009. Antibacterial activity of salt marsh halophytes and mangrove plants against methicillin resistant Staphylococcus aureus. World J. Microbiol. Biotechnol., 25: 155-160.

Desai, M.N. and N.S. Chavan, 2010. Antibacterial activity and phytochemical screening of Cynometra iripa kostel. Int. J. Pharma BioSci., 1: 1-4.

Devi, P., W. Solimabi, L. DSouza, S. Sonak, S. Y. Kamat and S.Y.S. Singbal, 1997. Screening of some marine plants for activity against marine fouling bacteria. Bot. Mar., 40: 87-91.

Eloff, J.N., 1998. A sentive and quick microplate method to determine the minimal inhibitory concentration of plant extracts for bacteria. Planta Med., 64: 711-713.

Ghani, A., 2003. Medicinal Plants of Bangladesh. 2nd Edn., The Asiatic Society of Bangladesh, Dhaka, Bangladesh, pp: 228-229.

Ilavenil, S., B. Kaleeswaran and S. Ravikumar, 2010. Evaluation of antibacterial activity and phytochemical analysis of Crinum asiaticum. Int. J. Curr. Res., 1: 35-40.

Kokpal, V., D.H. Miles, A.M. Payne and V. Chittawon, 1990. Chemical constituents and bioactive compounds from mangrove plants. Stud. Natl. Prod. Chem., 7: 175-199.

Kumar, R.S., G. Ramanathan, M. Subhakaran and S.J. Inbaneson, 2009. Antimicrobial compounds from marine halophytes for silkworm disease treatment. Int. J. Med. Med. Sci., 1: 184-191.

Lim, S.H., I. Darah and K. Jain, 2006. Antimicrobial activities of tannins extracted from Rhizophora apiculata barks. J. Trop. For. Sci., 18: 59-65.

Manilal, A., S. Sujith, G.S. Kiran, J. Selvin and C. Shakir, 2009. Biopotentials of mangroves collected from the Southwest coast of India. Global J. Biotechnol. Biochem., 4: 59-65.

Manilal, A., S. Sujith, G.S. Kiran, J. Selvin, C. Shakir and A.P. Lipton, 2010. Antimicrobial potential of marine organisms collected from the Southwest coast of India against multiresistant human and shrimp pathogens. Sci. Mar., 74: 287-296. 
Meyer, B.N., N.R. Ferrigni, J.E. Putnam, L.B. Jacobsen, D.E. Nichols and J.L. McLaughlin, 1982. Brine shrimp: A convenient general bioassay for active plants constituents. Planta Med., 45: 31-34.

Mishra, P.M. and A. Sree, 2007. Antibacterial activity and GCMS analysis of the extract of leaves of Finlaysonia obovata (A Mangrove Plant). Asian J. Plant Sci., 6: 168-172.

NCCLS, 2001. Antimicrobial susceptibility testing: 11th informationsupplement. NCCLSDocumentM100-S1 1 NCCLS, Pennsylvania, USA.

Patra, J.K., T.K. Panigrahi, S.K. Rath, N.K. Dhal and H. Thatoi, 2009. Phytochemical screening and antimicrobial assessment of leaf extracts of Excoecaria agallocha L.: A mangal species of Bhitarkanika, Orissa, India. Adv. Nat. Applied Sci., 3: 241-246.

Pisutthanana, S., P. Plianbangchangb, N. Pisutthanana, S. Ruanruaya and O. Muanrita, 2004. Brine shrimp lethality activity of thai medicinal plants in the family meliaceae. Naresuan Univ. J., 12: 13-18.
Ravikumar, S., M. Gnanadesigan, P. Suganthi and A. Ramalakshmi, 2010. Antibacterial potential of chosen mangrove plants against isolated urinary tract infectious bacterial pathogens. Int. J. Med. Medi. Sci., 2: 94-99.

Scherrer, R. and P. Gerhardt, 1971. Molecular sieving by the Bacillus megaterium cell wall and protoplast. J. Bacteriol., 107: 718-735.

Sharma, A., V.K. Patel and A.N. Chaturvedi, 2009. Vibriocidal activity of certain medicinal plants used in India folklore medicine. Indian J. Pharmacol., 41: 129-133.

Subhan, N., M.A. Alam, F. Ahmed, I.J. Shahid, L. Nahar and S.D. Sarker, 2008. Bioactivity of Excoecaria agallocha. Braz. J. Pharmacognosy, 18: 521-526.

Vadlapudi, V. and K.C. Naidu, 2009. In vitro antimicrobial activity Ceriops decandra against selected aquatic, human and phytopathogens. Int. J. Chem Tech. Res., 1: $1236-1238$

Xie, L.S., Y.K. Liao, Q.F. Huang and M.C. Huang, 2005. Pharmacognostic studies on mangrove Acanthus ilicifolius. Zhongguo Zhong Yao Za Zhi, 30: $1501-1503$. 